\title{
Gambaran Karakteristik Penderita Retinopati Hipertensi Yang Datang Berobat Ke Poliklinik Mata RSUP DR. M. Djamil Padang.
}

\author{
Adila Hanna ${ }^{1}$, Hendriati ${ }^{2}$, Kemala Sayuti ${ }^{3}$
}

\begin{abstract}
Abstrak
Retinopati hipertensi merupakan salah satu kerusakan target organ akibat tekanan darah tinggi, yang dapat menimbulkan kelainan-kelainan retina dan pembuluh darah di retina. Tujuan penelitian ini adalah mengindentifikasi gambaran karakteristik penderita retinopati hipertensi di RSUP DR. M. Djamil Padang dari tahun 2015 sampai 2016. Jenis penelitian ini adalah deskriptif dengan desain cross sectional. Penelitian ini dilakukan dari November sampai Februari 2018 di ruang pusat rekam medis RSUP DR. M. Djamil Padang. Sampel terdiri dari 80 rekam medik penderita yang didiagnosis dengan retinopati hipertensi yang tercatat di rekam medis. Dari 80 rekam medik, 74 rekam medik penderita memenuhi kriteria sampel.Dari 74 pasien, mayoritas penderita berumur $>60$ tahun (dengan rata-rata berumur 57,6 tahun), jenis kelamin perempuan mendominasi $(51,4 \%)$, mayoritas penderita adalah bekerja menggurus rumah tangga $(31,1 \%)$, menderita hipertensi stadium 1 dan telah menderita hipertensi selama 1-5 tahun $(63,5 \%$, dengan rata-rata 5,5 tahun). Mayoritas penderita tidak memiliki kerusakan target organ lain. Simpulan studi ini ialah mayoritas penderita retinopati hipertensi di RSUP DR. M. Djamil Padang dari tahun 2015 sampai 2016 adalah perempuan dan berumur diatas 60 tahun. Mayoritas dari pasien adalah ibu rumah tangga, telah menderita hipertensi stadium 1 selama 1-5 tahun dan tidak memilki kerusakan target organ lain.
\end{abstract}

Kata kunci: retinopati hipertensi, hipertensi, kerusakan target organ

\section{Abstract}

Hypertensive retinopathy is one is one of target organ damages due to high blood pressure which causes the defects of retina and retinal vascularization. The objective of this study was to identify the characteristic of hypertensive retinopathy patients at RSUP DR. M. Djamil Padang from 2015 until 2016. This was a descriptive study with cross sectional design study. This study was held from November until February 2018 in the medical record center of RSUP DR. M. Djamil Padang. Samples consisted of 80 medical records of patients who were diagnosed with hypetensive retinopathy that was stated in medical record. From those 80 medical records, there were 74 medical records that qualified the sample criterias. Out of 74 patients, majority of patients had the age $>60$ years (with 57,6 as mean age), female were found preponderance $(51,4 \%)$, majority of patients were housewives $(31,1 \%)$, had stage 1 in hypertension $(45,9 \%)$ and had been suffering from hypertension for 1-5 years (63,5\%, with 5,5 as mean years). Majority of these patients didn't have other target organ damage. In conclusion, most of hypetensive retinopathy patients at RSUP Dr. M. Djamil Padang from 2015 until 2016 were females and above 60 years old. Most of the patients had occupation as housewives, had been having stage 1 hypertension for 1-5 years and didn't suffer from other target organ damage.

Keywords: hypertensive retinopathy, hypertension, target organ damage

Affiliasi penulis: 1. Prodi Kedokteran Fakultas Kedokteran Universitas Andalas Padang (FK Unand), 2. IImu Kesehatan Mata FK Unand, 3. IImu Kesehatan Mata FK Unand
Korespondensi: Adila Hanna, Email:

adilahanna.apple@gmail.com,Telp: 081266503766 


\section{PENDAHULUAN}

Hipertensi adalah tekanan darah persisten diatas atau sama dengan 140/90 mmHg. Persistensi peningkatan berarti meningkatnya tekanan darah tidak bersifat transien atau hanya merupakan peningkatan diurnal dari tekanan darah yang normal sesuai siklus sikardian. Banyak konsensus dan guideline dari grading hipertensi, salah satunya adalah JNC VII yang mengklasifikasikan pre-hipertensi dengan sistolik/ diastolik adalah 120-139/80-89, stadium 1 dengan sistolik/diastolik 140-159/90-99 dan stadium 2 dengan sistolik/diastolik > 160/100 mmHg. Hipertensi terbagi atas hipertensi primer dan hipertensi sekunder yang diketahui etiologinya. Hipertensi primer disebabkan karena etiologi yang tidak diketahui, namun ada faktor yang mempengaruhi seperti obesitas, resistensi insulin, asupan garam yang tinggi, konsumsi alkohol berlebihan, penuaan, gaya hidup sedenter, stres, asupan kalsium dan kalium yang rendah. ${ }^{1}$ Hipertensi sekunder diketahui etiologinya, seperti penyakit (gagal ginjal kronik) dan obat-obatan (prednison). ${ }^{2}$

World Health Organization (WHO) melaporkan, hipertensi merupakan masalah kesehatan yang mendunia, terutama pada negara dengan pendapatan rendah hingga menengah. Prevalensi hipertensi pada negara dengan pendapatan rendah hingga menengah lebih tinggi dibandingkan negara dengan pendapatan tinggi. ${ }^{3}$ Hipertensi masih menjadi tantangan besar di Indonesia yang adalah negara dengan pendapatan rendah hingga menengah. Hal ini dibuktikan dengan hipertensi merupakan salah satu penyakit yang paling sering ditemukan pada pelayanan kesehatan primer. Walaupun obat-obatan hipertensi yang efektif banyak tersedia dan mudah dijangkau, pengontrolan hipertensi masih belum adekuat. ${ }^{4}$ Prevalensi hipertensi di Indonesia adalah sebesar 26,5\%. Provinsi yang memiliki prevalensi tertinggi adalah Bangka Belitung (30,9\%), diikuti Kalimantan Selatan (30,8\%), Kalimantan Timur (29,6\%) dan Jawa Barat $(29,4 \%){ }^{5}$ Selain itu, Sumatera Barat memiliki prevalensi hipertensi pada penduduk usia diatas 18 tahun sebesar 7,8\% berdasarkan diagnosis oleh tenaga kesehatan, 7,9\% berdasarkan diagnosis oleh tenaga kesehatan atau minum obat hipertensi dan $22,6 \%$ berdasarkan hasil pengukuran. ${ }^{6}$
Konsekuensi buruk akibat hipertensi juga diperparah karena banyak orang yang terkena hipertensi juga memiliki faktor risiko lainnya yang tidak berhubungan langsung dengan hipertensi sehingga meningkatkan kemungkinan untuk serangan jantung, stroke dan gagal ginjal. Faktor resiko lainnya tersebut berupa merokok, obesitas, kolesterol tinggi dan diabetes mellitus. Pada tahun 2008, prevalensi dunia pada obesitas dan perokok (menjadi satu milyar penduduk) sudah menjadi dua kali lipat semenjak tahun 1980. Prevalensi dunia pada penduduk yang menderita kolesterol tinggi adalah 39\% dan pada penduduk yang menderita diabetes adalah $10 \%$ pada 25 tahun belakangan. ${ }^{3}$

Hipertensi yang tidak terkontrol akan menyebabkan kerusakan pada mikrosirkulasi retina yang akan berujung pada retinopati hipertensi. Retinopati hipertensi menunjukan temuan oftalmik terhadap kerusakan sekunder end-organ akibat hipertensi. Temuan oftalmik tersebut berupa kelainan pembuluh darah (penyempitan umum atau lokal), percabangan pembuluh darah yang tajam, fenomena crossing atau sklerosis pembuluh darah. ${ }^{7}$ Studi epidemiologi berbasis populasi untuk retinopati hipertensi dilakukan dengan pemeriksaan fotografi retina. Studi ini merupakan gabungan dari studi yang dilakukan di Amerika Serikat, Australia, Belanda, Singapura, Jepang dan Cina. Dalam satu dekade terakhir, data dari studi ini menunjukan bahwa retinopati hipertensi terjadi pada $3 \%$ hingga $14 \%$ orang dewasa yang tidak menderita diabetes dan berumur lebih dari 40 tahun. $^{8}$

Retinopati hipertensi telah menjadi marker dari kerusakan mikrovaskular organ lain selama satu dekade terakhir. ${ }^{8}$ Data dari studi berbasis populasi menunjukan bahwa retinopati hipertensi berhubungan dengan meningkatnya resiko penyakit kardiovaskular, independen dari faktor resiko lainnya. TheAtherosclerosis Risk in Communities (ARIC) melaporkan individu dengan mikroaneurisma, perdarahan retina dan soft exudate kemungkinan 2-3 kali lebih beresiko menderita stroke dibandingkan dengan individu tanpa lesi retina, bebas dari diabetes, merokok, dislipidemia dan faktor resiko lainnya. Studi ini juga menunjukan bahwa retinopati hipertensi 
berhubungan erat dengan tekanan darah tinggi, namun tidak berhubungan erat dengan kadar kolesterol tinggi dan faktor resiko arterosklerosis lainnya. Evaluasi temuan retinopati hipertensi berkaitan dengan resiko penyakit kardiovaskular lainnya juga didukung oleh lembaga manajemen hipertensi internasional, termasuk JNC (Joint National Comitee) VII dan British Hypertension Society. Kedua lembaga ini menyebutkan bahwa retinopati hipertensi bisa dievalulasi sebagai indikator terhadap kerusakan end-organ, yaitu hipertrofi ventrikel kiri dan gagal ginjal kronik. $^{9}$

\section{METODE}

Jenis penelitian yang dilakukan adalah deskriptif dengan desain cross sectional study. Penelitian ini dilakukan setelah mendapat kelayakan etik (ethical clearance) dari Komisi Etik Penelitian Fakultas Kedokteran Universitas Andalas dengan nomor surat 477/KEP/FK/2017. Populasi pada penelitian ini adalah semua rekam medik penderita retinopati hipertensi yang datang berobat di Poliklinik Mata RSUP DR. M. Djamil Padang periode 2015 dan 2016. Kriteria inklusi adalah semua rekam medik penderita retinopati hipertensi yang datang berobat ke Poliklinik Mata RSUP DR. M. Djamil Padang periode 2015 dan 2016 yang memiliki kelengkapan data rekam medik. Kriteria eksklusi adalah rekam medik penderita retinopati hipertensi yang berobat ke Poliklinik Mata RSUP DR. M. Djamil Padang periode 2015 dan 2016 yang juga memiliki penyakit retinopati diabetes, sindroma hiperviskositas, retinopati akibat radiasi atau sindroma okular iskemik. Teknik pengambilan sampel menggunakan total sampling, sehingga didapatkan total jumlah sampel sebanyak 74 sampel.

Penelitian telah dilakukan dari 15 Januari 2017 hingga 15 Februari 2015 di RSUP DR. M. Djamil Padang. Data didapat dan dikumpulkan dari seluruh rekam medik pasien yang didiagnosis retinopati hipertensi. Data kemudian dicatat menurut usia, jenis kelamin, pekerjaan, stadium hipertens, stadium retinopati hipertensi, lama menderita hipertensi dan kerusakan target organ lain. Data kemudian diolah secara manual.
HASIL

Tabel 1. Distribusi frekuensi pasien retinopati hipertensi berdasarkan usia

\begin{tabular}{ccc}
\hline Usia & $\mathbf{f}$ & $\%$ \\
\hline$<40$ tahun & 3 & $4,0 \%$ \\
$40-49$ tahun & 7 & $9,5 \%$ \\
$50-59$ tahun & 25 & $33,8 \%$ \\
$>60$ tahun & 39 & $52,7 \%$ \\
\hline & 74 & $100 \%$ \\
\hline
\end{tabular}

Pada tabel diatas didapatkan lebih dari separuh $(52,7 \%)$ penderita retinopati hipertensi berusia diatas 60 tahun dan hanya sebagian kecil (4\%) yang berusia kurang dari 40 tahun.

Tabel 2. Distribusi frekuensi pasien retinopati hipertensi berdasarkan jenis kelamin

\begin{tabular}{ccc}
\hline Jenis Kelamin & $\mathbf{f}$ & $\%$ \\
\hline Laki-laki & 36 & $48,6 \%$ \\
Perempuan & 38 & $51,4 \%$ \\
\hline & 74 & $100 \%$ \\
\hline
\end{tabular}

Pada Tabel 2 didapatkan lebih dari separuh $(51,4 \%)$ penderita retinopati hipertensi memiliki jenis kelamin perempuan dan hampir dari separuh $(48,6 \%)$ penderita retinopati hipertensi memiliki jenis kelamin laki-laki.

Tabel 3. Distribusi frekuensi pasien retinopati hipertensi berdasarkan pekerjaan

\begin{tabular}{ccc}
\hline Pekerjaan & f & $\%$ \\
\hline Mengurus Rumah & 23 & $31,1 \%$ \\
Tangga & 1 & $1,3 \%$ \\
Pelajar/Mahasiswa & 12 & $16,2 \%$ \\
Pensiunan & 15 & $20,3 \%$ \\
Pegawai Negeri Sipil & 2 & $2,7 \%$ \\
Transportasi & 6 & $8,1 \%$ \\
Wiraswasta & 15 & $20,3 \%$ \\
Lainnya & 74 & $100 \%$ \\
\hline
\end{tabular}

Pada Tabel 3 didapatkan hampir dari separuh $(31,1 \%)$ penderita retinopati hipertensi memiliki pekerjaan adalah mengurus rumah tangga dan sebagian kecil (1,3\%) memiliki pekerjaaan sebagai pelajar/mahasiswa. 
Tabel 4. Distribusi frekuensi pasien retinopati hipertensi berdasarkan stadium hipertensi

\begin{tabular}{ccc}
\hline Stadium Hipertensi & f & $\%$ \\
\hline Prehipertensi & 25 & $33,7 \%$ \\
Stadium 1 & 34 & $45,9 \%$ \\
Stadium 2 & 15 & $20,3 \%$ \\
\hline
\end{tabular}

Pada Tabel 4 didapatkan hampir dari separuh $(45,9 \%)$ penderita retinopati hipertensi menderita stadium hipertensi 1 dan sebagian kecil (20,3\%) menderita hipertensi stadium 2.

Tabel 5. Distribusi frekuensi pasien retinopati hipertensi berdasarkan stadium retinopati hipertensi

\begin{tabular}{lcc}
\hline $\begin{array}{c}\text { Stadium Retinopati } \\
\text { Hipertensi }\end{array}$ & $\mathbf{f}$ & $\%$ \\
\hline KW I & 25 & $33,8 \%$ \\
KW I-II & 4 & $5,4 \%$ \\
KW II & 38 & $51,3 \%$ \\
KW II-III & 1 & $1,3 \%$ \\
KW III & 3 & $4,1 \%$ \\
KW IV & 3 & $4,1 \%$ \\
\hline & 74 & $100 \%$ \\
\hline
\end{tabular}

Pada Tabel 5 didapatkan lebih dari separuh $(51,3 \%)$ penderita retinopati hipertensi menderita retinopati hipertensi stadium II dan sebagian kecil $(1,3 \%)$ menderita retinopati hipertensi KW II-III.

Tabel 6. Distribusi frekuensi pasien retinopati hipertensi berdasarkan lama menderita hipertensi

\begin{tabular}{ccc}
\hline $\begin{array}{c}\text { Lama Menderita } \\
\text { Hipertensi }\end{array}$ & $\mathbf{f}$ & $\%$ \\
\hline $1-5$ th & 47 & $63,5 \%$ \\
$6-10$ th & 20 & $27 \%$ \\
$>10$ th & 7 & $9,5 \%$ \\
\hline & 74 & $100 \%$ \\
\hline
\end{tabular}

Pada Tabel 6 didapatkan lebih dari separuh $(63,5 \%)$ penderita retinopati hipertensi menderita hipertensi selama 1-5 tahun dan hanya sebagian kecil menderita hipertensi lebih dari 10 tahun (9,5\%).
Tabel 7. Distribusi frekuensi pasien retinopati hipertensi berdasarkan kerusakan target organ lain

\begin{tabular}{ccc}
\hline $\begin{array}{c}\text { Kerusakan Target } \\
\text { Organ Lain }\end{array}$ & $\mathbf{f}$ & $\%$ \\
\hline SSP & 5 & $6,7 \%$ \\
Jantung & 22 & $29,7 \%$ \\
Ginjal & 2 & $2,7 \%$ \\
Tidak Ada & 48 & $64,9 \%$ \\
\hline & 74 & \\
\hline
\end{tabular}

Pada Tabel 7 didapatkan lebih dari separuh penderita retinopati hipertensi tidak menderita kerusakan target organ lain (64,9\%) dan sebagian kecil $(2 \%)$ menderita kerusakan target organ ginjal.

\section{PEMBAHASAN}

Studi oleh Leung et al tahun 2003 di Blue Mountain, Australia yang menggunakan funduskopi retina dan perangkat lunak Retinal Analysis pada 3355 laki-laki dan perempuan berumur 49 tahun keatas, menunjukan setiap kenaikan umur satu dekade pada laki-laki dan perempuan, rata-rata CRAE (central retinal artery equivalent, rata-rata lebar arteriol) pada laki-laki dan wanita menurun 4,2 $\mu \mathrm{m}-5,7 \mu \mathrm{m}$ dan ratarata CRVE pada laki-laki dan wanita (central retinal vein equivalent, rata-rata lebar venula) menurun 3,9 $\mu \mathrm{m}$. Rata-rata AVR (arteriol to venule ratio, didapatkan dari CRAE dibagi CRVE) juga menurun seiring bertambahnya usia, yaitu menurun $0,01 \mu \mathrm{m}$ saat mencapai usia 80 tahun. $^{10}$ Oleh karena itu, dapat disimpulkan bahwa arteriol dan venula semakin menyempit seiring bertambahnya usia, sehingga, retinopati hipertensi akan semakin sering ditemukan pada usia yang lebih tua. Hal ini juga didukung dengan perjalanan aterosklerosis yang akan semakin parah seiring bertambahnya usia, sehingga akan meningkatkan tekanan darah secara vasospastik dan memperburuk hipertensi, selanjutnya akan menyebabkan kerusakan target organ akibat hipertensi. ${ }^{11}$ 
NHANES II dan NHANES III menyimpulkan peningkatan tekanan darah pada perempuan yang melebihi peningkatan tekanan darah pada laki-laki terjadi pada dekade kelima dan keenam kehidupan.26 Peningkatan tekanan darah pada perempuan terkait dengan perubahan hormonal yang terjadi saat perempuan setelah memasuki masa menopause. Estrogen mempunyai peran dalam melindungi wanita terhadap hipertensi. Estrogen menstimulasi produksi nitrit oksida (nitric oxide, NO) yang mempunyai peran dalam vasodilatasi pembuluh darah, sehingga dapat menurunkan tekanan darah. Estrogen tidak lagi diproduksi saat perempuan telah memasuki masa menopause, sehingga tidak lagi ada efek protektif dari hipertensi pada perempuan yang telah memasuki masa menopause. ${ }^{11}$ Perubahan kadar androgen juga ikut berperan dalam tingginya tekanan darah pada perempuan pasca-menopause, hal ini disebabkan karena androgen mempengaruhi reabsorbsi natrium pada nefron ginjal dan menstimulasi sistem reninangiotensin, sehingga memberikan pengaruh terhadap tingginya tekanan darah. ${ }^{12}$ Banyak penderita hipertensi yang berjenis kelamin perempuan, maka wanita juga akan lebih banyak menderita kerusakan organ akibat hipertensi, salah satunya ialah retinopati hipertensi.

Kejadian hipertensi berhubungan dengan aktivitas fisik yang dilakukan oleh seseorang. Pada studi ACLS, kebugaran kardiorespirasi yang baik akan menurunkan angka kejadian hipertensi. Studi tersebut membagi dua kategori sampel, orang dengan kebugaran kardiorespirasi yang baik dan orang dengan kebugaran kardiorespirasi yang tidak baik. Orang dengan kebugaran respirasi yang baik dilaporkan memiliki 26-28\% angka kejadian hipertensi yang lebih rendah dibandingkan orang dengan kebugaran kardiorespirasi yang tidak baik. Kebugaran kardiorespirasi dan jasmani bergantung dengan seberapa banyak aktivitas fisik yang dilakukan seseorang. Aktivitas fisik adalah gerakan tubuh yang dihasilkan oleh kontraksi otot rangka yang meningkatkan pengeluaran energi melebihi energi yang digunakan saat istirahat, terdiri dari kegiatan sehari-hari seperti berjalan, pekerjaan rumah tangga, pekerjaan di tempat kerja dan kegiatan khusus yang memang dilakukan untuk meningkatkan kesehatan. Penemuan terbaru menunjukan bahwa aktivitas fisik berupa olahraga aerobik mencegah naiknya tekanan darah dengan mengatur sensitivitas insulin dan fungsi sistem saraf otonom, selain itu aktivitas fisik berupa latihan ketahanan mencegah naiknya tekanan darah dengan mengatur vasokonstriksi pembuluh darah. lbu rumah tangga memang rutin melakukan aktivitas fisik berupa pekerjaan rumah tangga, namun tidak diiringi dengan dilakukannya aktivas fisik khusus yang dapat menurunkan tekanan darah. Ibu rumah tangga yang menderita hipertensi menjadi lebih banyak sehingga lebih banyak pula yang menderita retinopati hipertensi. ${ }^{13}$

Penyempitan arteriol merupakan tanda awal dari retinopati hipertensi. CHS (Cardiovascular Health Study) dengan 2405 sampel menunjukan lebar arteriol akan berkurang dengan bertambah tingginya tekanan darah sistolik dan diastolik pada laki-laki dan perempuan berumur 69-79 tahun. ARIC study menunjukan berkurangnya AVR dalam waktu 3-6 tahun jika tekanan darah menetap ataupun bertambah. Dilihat dari MAP (mean arterial blood pressure), ketika MAP meningkat dari $80 \mathrm{mmHg}$ sampai $131 \mathrm{mmHg}$, CRAE akan menurun secara konstan dari $203 \mu \mathrm{m}$ sampai $180 \mu \mathrm{m}$, namun ketika MAP meningkat dari $131 \mathrm{mmHg}$, CRAE akan meningkat dari $180 \mu \mathrm{m}$. Hal yang sama terjadi pada CRVE, ketika MAP meningkat dari $80 \mathrm{mmHg}$ sampai $131 \mathrm{mmHg}$, CRVE akan menurun secara konstan dari $230 \mu \mathrm{m}$ sampai $220 \mu \mathrm{m}$, namun ketika MAP meningkat dari $131 \mathrm{mmHg}$, CRVE akan meningkat dari $220 \mathrm{mmHg}$. Arteriol dan venul akan menyempit seiiring dengan peningkatan tekanan darah (sampai hipertensi stadium 1) namun akan kembali melebar jika tekanan darah sudah terlalu tinggi (melewati hipertensi stadium 1), sehingga penderita retinopati hipertensi yang paling banyak adalah penderita yang menderita hipertensi stadium 1 lalu diikuti dengan prehipertensi, dikarenakan pada hipertensi stadium 2, arteriol dan venul tidak lagi menurun, namun malah melebar. Penderita prehipertensi adalah penderita yang menderita hipertensi sejak lama, namun terkontrol dengan obat-obatan hipertensi. ${ }^{10}$ Sesuai 
dengan studi yang dilakukan oleh Mondal et al di Bangladesh pada tahun 2017, dengan 384 sampel, menunujukan lebih banyak penderita retinopati hipertensi dengan tekanan darah terkontrol (54\%) dibanding tekanan darah tidak terkontrol (46\%). ${ }^{14}$

Pada tabel diatas didapatkan distribusi frekuensi retinopati hipertensi terbanyak yaitu penderita stadium retinopati hipertensi KW II dengan hipertensi stadium pre-hipertensi dan yang paling sedikit adalah stadium retinopati hipertensi KW II-III dengan stadium hipertensi 2. Penelitian yang dilakukan di Bangladesh pada tahun 2017 menunjukan hampir semua pasien menderita retinopati hipertensi $\mathrm{KW}$ I, namun, kaitan retinopati hipertensi dan stadium hipertensi tidak diteliti dalam penelitian tersebut. ${ }^{14}$ Penelitian yang dilakukan di Meksiko pada tahun 2013 juga menunjukan hampir semua pasien menderita retinopati hipertensi stadium 1. Pada penelitian terlihat penderita retinopati hipertensi terbanyak yaitu stadium KW II dengan pre-hipertensi, dalam rekam medis penderita tersebut terlihat hampir semua penderita telah menderita hipertensi dalam jangka lama, namun terkontrol oleh obat-obatan. Sesuai dengan penelitian yang dilakukan di Bangladesh, stadium retinopati hipertensi lebih mudah berkembang pada penderita dengan hipertensi yang terkontrol dibandingkan dengan yang tidak terkontrol. ${ }^{14}$ Penelitian yang dilakukan oleh Henderson et al pada tahun 2011 di Amerika Serikat juga menunjukan, bahwa hipertensi kronik dapat memberikan efek protektif terhadap perkembangan retinopati hipertensi dibandingkan hipertensi akut (yang biasanya diakibatkan oleh hipertensi akut atau hipertensi sekunder) yang langsung menyebabkan retinopati hipertensi stadium III-IV. Pada penelitian tersebut terlihat penderita retinopati hipertensi stadium III-IV berumur rata-rata 16 tahun lebih muda dibanding keseluruhan penderita dan juga menderita penyakit hipertensi sekunder. ${ }^{16}$ Penelitian yang dilakukan di RSUP DR. M. Djamil juga terlihat dua dari tiga orang penderita dengan retinopati hipertensi stadium IV menderita hipertensi stadium dua, yang kemungkinan berhubungan dengan hipertensi akut atau hipertensi sekunder.
Keterbatasan dari penelitian ini adalah jumlah sampel yang sedikit dan tidak dikajinya riwayat penyakit hipertensi akut atau sekunder dari anamnesis di rekam medik tersebut.

Hasil penelitian karakteristik penderita retinopati hipertensi yang datang berobat ke Poli Mata RSUP DR. M. Djamil, telah didapatkan penderita retinopati hipertensi terbanyak menderita hipertensi selama 1-5 tahun yaitu sebanyak 47 orang $(63,5 \%)$ dengan rata-rata seluruhnya menderita hipertensi selama 5,5 tahun. Penelitian yang dilakukan oleh Monalisa pada tahun 2013 di RSUP H Adam Malik Medan penderita retinopati hipertensi terbanyak menderita hipertensi selama 510 tahun yaitu sebanyak 30 orang (52,6\%), sedangkan yang menderita hipertensi <5 tahun adalah sebanyak 25 orang (43,9\%). ${ }^{17}$ Perbedaan dengan penelitian Monalisa diakibatkan karena jumlah sampel yang lebih sedikit yaitu sebanyak 57 sampel, selain itu tidak ditemukan perbedaan yang begitu jauh dari lama menderita hipertensi selama $<5$ tahun dan selama 5-10 tahun. Penelitian di Bangladesh oleh Mondal, et al pada tahun 2017 menunjukan hal yang sama, yaitu penderita retinopati hipertensi terbanyak menderita hipertensi selama $>5$ tahun $(69,13 \%)$ dengan rata-rata 6,7 tahun. ${ }^{14}$ Perbedaan hasil penelitian ini dikarenakan banyaknya pasien di RSUP DR M. Djamil yang tidak pernah kontrol hipertensi sebelum keluhan retinopati hipertensi muncul, sehingga baru diketahui menderita hipertensi saat pertama kali kontrol ke Poli Mata, sedangkan penelitian di Bangladesh memang dilaksanakan di OPD (Out Patient Department) di Pusat Penelitian Hipertensi, sehingga pasien yang diteliti telah mengetahui dirinya telah menderita hipertensi sebelumnya. Lama menderita hipertensi dihitung dari pertama kali pasien datang ke RSUP DR. M. Djamil dengan atau disertai hipertensi, bukan dari hasil anamnesis lengkap, dikarenakan tidak lengkapnya data anamnesis pada pada rekam medik. Sehingga, hal ini dapat mengurangi keakuratan dari hasil penelitian. Menurut penelitian lain, tidak ditemukan hubungan lamanya menderita hipertensi dengan kejadian retinopati hipertensi, yang berhubungan 
secara langsung adalah meningkatnya umur dengan angka kejadian dan keparahan retinopati hipertensi. ${ }^{18}$ Studi di Bangladesh juga menunjukan hal yang sama, bahwa lamanya menderita hipertensi tidak mempengaruhi angka kejadian dan keparahan retinopati hipertensi. ${ }^{14}$

Hipertensi dengan kontrol yang buruk dapat menyebabkan komplikasi pada kardiovaskular, SSP, ginjal dan retina. Hipertensi tersebut akan menyebabkan terjadinya hipertofi ventrikel kiri yang dapat berlanjut menjadi penyakit kardiovaskular lainnya, seperti iskemia miokard, serta penyakit SSP, yaitu stroke iskemik. Oleh karena itu, dapat dilihat pada hasil penelitian bahwa pada pasien retinopati hipertensi yang juga menderita kerusakan pada jantung, tidak hanya menderita dari satu penyakit jantung saja, namun juga menderita penyakit jantung lainnya. Dari data juga didapatkan, bahwa tiga pasien retinopati hipertensi dengan kerusakan jantung, juga menderita stroke iskemik, hal ini merupakan kelanjutan dari penyakit pada jantung. Studi CRIC (Chronic Renal Insufficiency Cohort) menunjukan adanya hubungan antara derajat keparahan retinopati hipertensi dengan penyakit kardiovaskular, selanjutnya, studi oleh NHANES I melaporkan terjadinya peningkatan resiko penyakit kardiovaskular pada penderita retinopati hipertensi. ${ }^{18}$ Arteriol retina memiliki persamaan struktur anatomis (yaitu sawar darahotak) dan fungsi fisiologis (yaitu regulasi tekanan darah) dengan arteriol serebral, sehingga perubahan dalam diameter arteriol retina juga menggambarkan perubahan pada arteriol serebral, perubahan pada arteriol retina dapat digunakan sebagai prediksi kelainan pada SSP. ${ }^{18}$ Studi yang dilakukan oleh Longstreth et al pada tahun 2007 juga menunjukan adanya hubungan yang jelas dari kelainan arteriol akibat retinopati hipertensi (diteliti melalui funduskopi) dan stroke klinis atau subklinis (diteliti melalui CT-scan). ${ }^{19}$ Arteriol retina juga memiliki kesamaan dengan arteriol di ginjal, namun bukanlah persamaan dalam anatomis dan fungsi fisiologis, namun persamaan dalam mekanisme patofisiologi dalam penyakitnya. ${ }^{18}$ Studi yang dilakukan oleh Grundwald et al pada tahun 2012 di Amerika Serikat menunjukan bahwa retinopati hipertensi dan gagal ginjal kronik memiliki persamaan dalam perubahan endotel, yaitu penebalan membran basalis, lapisan muskular dan kebocoran. Penyempitan venula retina juga berhubungan dengan GFR (glomerulous filtration rate) yang rendah. ${ }^{20} \mathrm{Hal}$ ini didukung oleh penelitian lain yang dilakukan oleh Shantha et al di India Selatan pada tahun 2010 yang menyimpulkan bahwa retinopati hipertensi dalam tiap stadium mempunyai akurasi yang sedang sebagai indikator untuk memprediksi mikroalbuminuria. ${ }^{21}$ Besarnya jumlah pasien retinopati hipertensi tanpa diikuti kerusakan target organ lain dibandingkan dengan pasien retinopati hipertensi diikuti kerusakan organ lain dapat dikarenakan kerusakan organ lain yang diderita belum simptomatis sehingga dilakukan pemeriksaan terhadap organ lain tersebut. Alasan lain yang menyebabkan ialah pasien dengan kerusakan organ lain, sudah memiliki banyak komplikasi dalam target organnya sehingga sudah banyak yang meninggal dikarenakan fungsi jantung yang terganggu pertama kali, sehingga menambah resiko komplikasi terhadap target organ lainnya.

\section{SIMPULAN}

Penderita retinopati hipertensi hampir dari separuh menderita hipertensi stadium 1, penderita retinopati hipertensi lebih dari separuh menderita retinopati hipertensi stadium KW II, penderita retinopati hipertensi lebih dari separuh menderita hipertensi selama 1-5 tahun, penderita retinopati hipertensi lebih dari separuh tidak memiliki kerusakan target organ lain.

\section{DAFTAR PUSTAKA}

1. Carretero OA, Oparil S. Essential hypertension part I: definition and etiology. Circulation. 2000;101: 329-35.

2. Yogiantoro M. Pendekatan klinis hipertensi. Dalam: Setiati S, Alwi I, Sudoyo AW, Simadibrata M, Setiyohadi B, Syam AF, editor (penyunting). Buku ajar ilmu penyakit dalam jilid II. Edisi ke-6. Jakarta: Interna Publishing; 2014.hlm.2259-82. 
3. World Health Organization (WHO). A global brief on hypertension: silent killer. Global Public Health Crisis. 2013 Des (diunduh 1 Oktober 2017).

Tersedia dari: http://apps.who.int/iris/bitstream/ 10665/79059/1/WHO DCO WHD $2013.2 \mathrm{eng}$ .pdf?ua $=1$

4. Departemen Kesehatan RI (Depkes RI) Hipertensi. InfoDatin Pusat Data dan Informasi Kementrian Kesehatan RI: 2014 Jan (diunduh Oktober 2017). Tersedia dari: http://www.depkes.go.id/resources/download/pusd atin/infodatin/infodatin-hipertensi.pdf

5. Departemen Kesehatan RI (Depkes RI). Riset kesehatan dasar dalam angka (Riskesdas) 2013. Badan Penelitian dan Pengembangan Kesehatan Kementerian RI; 2013 Jan (diunduh Oktober 2017). Tersedia dari:

http://www.depkes.go.id/resources/download/gener al/Hasil\%20Riskesdas\%202013.pdf

6. Departemen Kesehatan RI (Depkes RI). Riset kesehatan dasar dalam angka (Riskesdas). Badan Penelitian dan Pengembangan Kesehatan Kementerian RI. Provinsi Sumatera Barat. 2013 Jan (diunduh Oktober 2017). Tersedia dari: http://terbitan.litbang.depkes.go.id/penerbitan/index .php/lpb/catalog/book/138

7. Grosso A, Veglio F, Porta M, Grignolo FM, Wong TY. Hypertensive retinopathy revisited: some answers, more questions. $\mathrm{Br} \mathrm{J}$ Ophthalmol. 2005;89:1646-54.

8. Bhargava M, Wong TY. Current concepts in hypertensive retinopathy: the retinal physician is often the first to detect It. 2013 Feb (diunduh Oktober 2017). Tersedia dari: https://www.retinalphysician.com/issues/2013/novdec/current-concepts-in-hypertensive-retinopathy

9. Erden S, Bicakci E. Hypertensive retinopathy: incidence, risk factors, and comorbidities. clinical and experimental. Hypertension, 2012;34(6): 397401.

10. Leung, Harry, Wang JJ, Rochtchina E, Tan AG, Wong TY, Klein R, et al. Relationship between age, blood pressure and retinal vessel diameters in an older population. Invest Ophhalmol Vis Sci. 2003; 44:2900-4.
11. Burl VL, Whelton $P$, Roccella EJ, Brown $C$, Cutler JA, Higgins M, Horan MJ, Labarthe D. Prevalence of hypertension in the US adult population: results from the third national health and nutrition examination survey 1988-1991. Hypertension. 1995;25:305-13.

12. The Writing Group for the PEPI Trial. Effects of estrogen or estrogen/progestin regimens on heart disease risk factors in postmenopausal women: the postmenopausal estrogen/progestin inverventions (PEPI) trial. JAMA. 1995;273:1379-86.

13. Diaz KM, Shimbo D. Physical activity and the prevention of hypertension. Curr Hypertens Rep. 2013;15(6):659-68.

14. Mondal RN, Matin MA, Rani m, Hossain ZM, Shaha AC, Singh RB, et al. Prevalence and risk factors of hypertensive retinopathy in hypertensive patients. J Hypertens. 2017;6:241.

15. Henderson DA, Blousse V, Newman NJ, Lamirel C, David WW, Bruce BB. Grade III or grade IV hypertensive retinopathy with severly elevated blood pressure. West J Emerg Med. 2012; 13(6):529-34.

16. Henderson DA, Blousse V, Newman NJ, Lamirel C, David WW, Bruce BB. Grade III or grade IV hypertensive retinopathy with severly elevated blood pressure. West J Emerg Med, 2012; 13(6):529-34.

17. Monalisa M. Karakteristik penderita retinopati hipertensi yang datang berobat ke poliklinik mata RSUP H. Adam Malik Medan periode Januari 2012-Mei 2013 (skripsi). Medan: Universitas Sumatera Utara; 2013.

18. Kabedi NN, Mwanza JC, Lepira FB, Kayembe TK, Kayembe DL. Hypertensive retinopathy and it's association with cardiovascular morbidity in Congolose patients. Cardiovasc J Afr. 2014; 25: 228-32.

19. Longstreth WJr, Larsen EK, Klein R. Retinal microvascular abnormalities and MRI-defined subclinical cerebral infarction: the atherosclerosis risk in community study. Stroke. 2006;37:82-6.

20. Grunwald JE, Alexander J, Ying GS, Maguire M, Daniel E, Martin RW, et al. Retinopathy and chonic kidney disease in the chronic renal inssuficiency 
cohort (CRIC) study. Arch Ophthalmol. 2012; 130(9):1136-44.

21. Shantha GP, Kumar AA, Bhaskar E, Sivagnanam $K$, Srinivasan D. Hypertensive retinal changes, a screening tool to predict microalbuminuria in hypertensive patients: a cross sectional study. Nephrol Dial Transplant. 2010;(25):1839-45. 